\title{
The Impact of Land Use Activities on Vegetation Cover and Water Quality in the Lake Victoria Watershed
}

\author{
Charles K. Twesigye ${ }^{1, *}$, Simon M. Onywere ${ }^{2}$, Zachary M. Getenga ${ }^{3}$, Shadrach S. Mwakalila ${ }^{4}$, \\ and Josephine K. Nakiranda ${ }^{5}$
}

\author{
${ }^{1}$ Kyambogo University, Dept. of Biological Sciences, P.O. Box 1 Kyambogo, Kampala, ${ }^{2}$ Kenyatta University, \\ Dept. of Env. Planning and Management, P.0. Box 43844, 00100 Nairobi, ${ }^{3}$ Masinde Muliro University of Science and \\ Technology, Department of Chemistry, P.O. Box 190, Kakamega, Kenya, ${ }^{4}$ University of Dar es Salaam, Department of \\ Geography, P.O. Box 35049, Dar es Salaam, ${ }^{5}$ Makerere University, P.O. Box 7062, Kampala
}

\begin{abstract}
The impact of land use activities on loss of vegetation cover and water quality was assessed in three selected sites within the Lake Victoria Basin using remote sensing technologies and standard water quality analysis techniques. The three study sites were: (i) Nzoia River Basin (Kenya), (ii) Nakivubo Wetland (Uganda) and (iii) Simiyu drainage basin (Tanzania). Lake Victoria is the second largest fresh water lake in the world and is served by a drainage basin area of over 193,000 km², traversing five East African Community States; Kenya, Uganda, Tanzania, Rwanda and Burundi. This paper examines the impact of land use activities on vegetation cover and water quality based on remote sensing and Geographical Information Systems analysis combined with chemical and physical water analysis. The quality of the effluent generated by the industries found within the study sites and their effects on downstream discharge was also determined. Pesticide residues in soil and water samples were determined using analytical standard methods. Soils from some selected fields in Nzoia River basin showed high levels of compounds such as aldrin, dieldrin, endosulfan, DDT, and endrin which are together referred to as persistent organic pollutants (POPs). The physical and chemical analysis of water quality revealed high levels of phosphates and nitrates along the agricultural zones of River Nzoia Basin. The satellite images revealed that in all the three study sites land vegetation cover has continuously reduced in size. The extent of environmental degradation caused by agricultural, domestic and industrial wastes and how this affects loss of vegetation cover and water quality is discussed.
\end{abstract}

Keywords: GIS analysis, Lake Victoria, land use, remote sensing, vegetation cover, water quality, watershed.

\section{INTRODUCTION}

Lake Victoria with a water surface area of $68,000 \mathrm{~km}^{2}$, is the second largest fresh water lake in the world with a drainage area of over 193,000 $\mathrm{km}^{2}$, traversing five Eastern Africa Community States of Burundi, Kenya, Rwanda, Tanzania and Uganda. The lake's freshness is maintained by discharge through the Nile River and recharge from numerous rivers among which are the Mara, Kagera and Nzoia. The lake is a common resource for Kenya, Uganda and Tanzania. It supports approximately 30 million people with a catchment population density of 170 persons per square Kilometre. Agriculture, livestock and fishing form the basis for the livelihood of the majority of the population. The lake and its catchment rivers are also sources of water, employment, transport, hydroelectric power and recreation. However the vitality of the lake has been affected by waste discharge from various activities around the lake $[1,2]$. The pollution impact by municipal and industrial discharges is visible in some of the rivers feeding the lake and along the shoreline such as at Port Victoria in Busia, Winam Gulf in Kisumu, Mwanza Gulf in Tanzania and Murchison Bay in Kampala.

*Address correspondence to this author at the Kyambogo University, Dept. of Biological Sciences, P.O. Box 1 Kyambogo, Kampala;

Tel: +256 782353 775; Fax: 0414220464; E-mail: twesigyeck@yahoo.com
Currently, concerns are being raised regionally and globally about the health of the basin with regard to pollution, overexploitation of its resources and technological developments affecting biodiversity and the overall function as a watershed $[3,4]$. Water pollution is ranked the major problem and it is currently suggested to be the leading cause of deaths and diseases. The largest proportion of this pollution is accounted for by chemical pollutants, nutrient discharge and sediment loading.

The wetlands of the Lake Victoria Drainage Basin (LVDB) provide several benefits to the local communities such as source of water for domestic consumption, fishing, agricultural production and water filtration $[4,5]$. Nakivubo swamp in Uganda for example has a fundamental function of regulating and buffering nutrient inputs and filtration of anthropogenic pollutants into Inner Murchison Bay. For over 35 years, the swamp has been the overall recipient of partially treated wastewater from the City of Kampala and storm water. The swamp's existence is further threatened by human encroachment through subsistence farming, settlements, burning, brick making and biomass harvesting for livestock.

The Simuyu drainage basin on the other hand comprises a diversity of habitats including swampy areas with cyperus papyrus, sedges, reeds and cattails, and rivers, ponds, sea- 


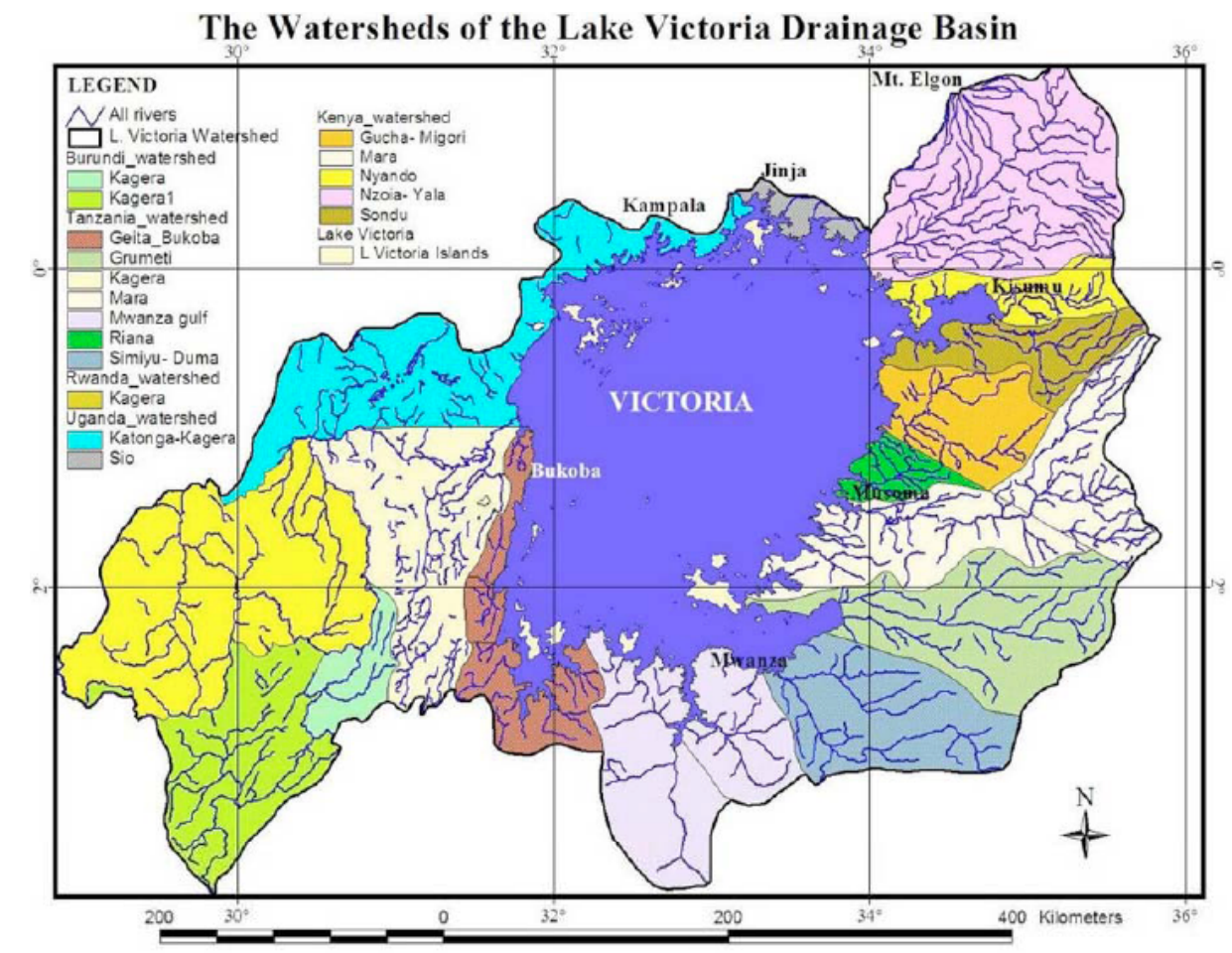

Fig. (1). The Watershed of Lake Victoria Drainage Basin.

sonally inundated grasslands and bushlands. The drainage basin's wetlands are mainly used for rice cultivation leading to the floodplains' draw-downs. The Nzoia basin is within a sugarcane growing region and a floodplain in Budalangi. Eutrophication of Lake Victoria has been identified as a major issue contributing to low ecosystem productivity [6] Whereas the impact of eutrophication on various Lake ecosystem functions and productivity has been quantified and well documented [7-11], the source of nutrient loading remains a controversial issue. Nutrient laden sediments are the major source of the lake's water quality problems along with waste water discharges from major urban areas around the lakeshore [12-14]. Rural areas have also taken the blame for sediment loading into Lake Victoria [7] from poor farming practices.

Studies on sediment yield in LVDB have been based on erosion models and soil loss data from runoff plots in agricultural fields [15-20]. Data on soil loss from settlements in the Lake Victoria catchment is lacking yet settlements are associated with gulley erosion [20] which is a major source of sediment [21]. The increasing magnitude of sediment pollution in Lake Victoria could be attributed to alteration of wetlands riparian areas through various land use changes and dynamics [11, 22-24]. It has been reported that about $75 \%$ of the Lake Victoria wetland area has been significantly affected by human activities of which about $13 \%$ is severely degraded [25]. Alteration of the riparian zones around Lake Victoria has rendered the protective nature of these areas ineffective or even detrimental to the health of the lake water. With the growing population the multiple activities in the lake basin have increasingly come into conflict, rendering the lake environmentally unstable. The scenarios on the impacts on the land and water resources formed the basis for this study which targeted the watersheds of Nakivubo Wetland (Uganda), Nzoia River Basin (Kenya) and Mwanza Gulf Drainage Basin (Tanzania) that are characterized by unique land use practices. The research adopted a multidisciplinary approach on bringing to the fore the various processes affecting wetland use and management in the study sites. Geographic information systems (GIS) and remote sensing techniques were used to unveil land use patterns that have resulted in the degradation of the wetlands.

In particular the study examined the impacts of land use activities on watershed resources using remote sensing techniques and GIS tools. It also assessed the extent of environmental degradation from agricultural, domestic and industrial activities and how this affects the quality of water in the Lake Victoria Basin.

\section{MATERIALS AND METHODOLOGY}

\section{Description of Study Area}

The Lake Victoria watershed covers a drainage area of over 193,000 km², traversing five Eastern Africa Community States of Burundi, Kenya, Rwanda, Tanzania and Uganda (Fig. 1).

Fig. (1) represents the major sub-basins of River Kagera and Katonga in the western part and River, Nzoia, Nyando, Mara and Yala in the eastern part of the basin. Simiyu River Basin forms the watershed on the southern part of the Lake Victoria Basin. With the growing population the multiple activities in the lake basin have increasingly come into conflict, rendering the lake environmentally unstable. The problems have arisen in the surrounding sub-basins due to population pressure on land and degradation of environmental resources and associated human activities. 


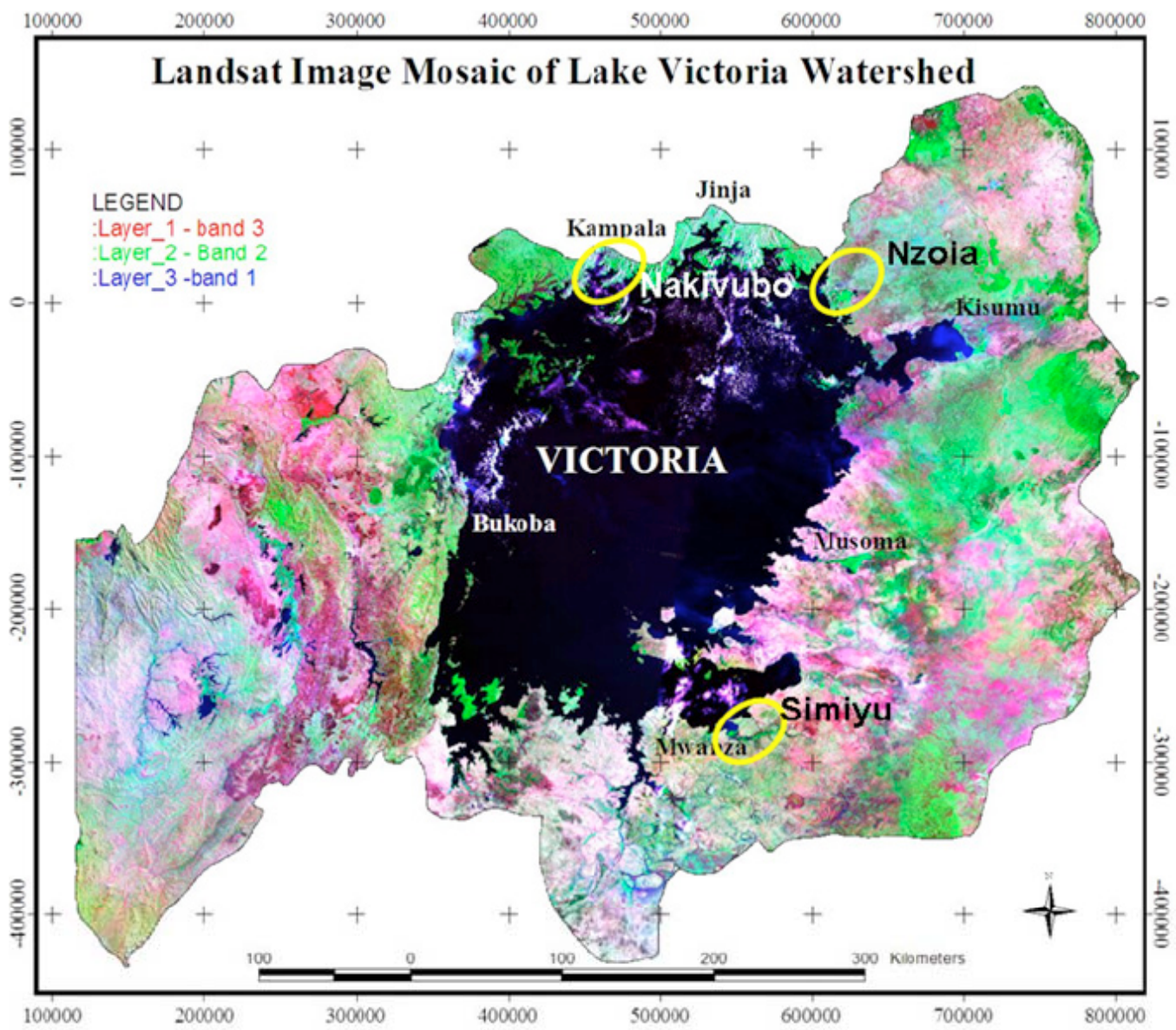

Fig. (2). Landsat satellite mosaic of LVDB showing location of the study sites of Nakivubo, Nzoia and Simiyu.

Three specific case study areas of Nakivubo Wetland (Uganda), Nzoia River Basin (Kenya) and Simiyu Drainage Basin (Tanzania) were investigated (Fig. 2). Nakivubo swamp is situated between latitudes $00^{\circ} 17^{\prime}$ and $00^{\circ} 19^{\prime} \mathrm{N}$ and longitudes $32^{\circ} 37^{\prime}$ and $32^{\circ} 39^{\prime} \mathrm{E}$, at an altitude of $1135 \mathrm{~m}$ above mean sea level. The swamp (a tropical perennial natural wetland) lies about $5 \mathrm{~km}$ south-east of Uganda's Capital City, Kampala and connects the City to the Inner Murchison Bay of Lake Victoria.

The Landsat Image Mosaic of Lake Victoria Watershed shows the three study sites (Fig. 2). Nzoa River basin covers the Budalangi floodplain area (Busia District) while Simiyu Drainage Basin is located in the Mwanza Region of Magu District (Tanzania). The study sites within the basin were at Nzoia Sugarcane growing area (Bungoma District) which lies between latitude $0^{\circ} 25.3^{\prime}$ and $0^{\circ} 53.2^{\prime}$ North and longitude $34^{\circ} 21.4^{\prime}$ and $35^{\circ} 04^{\prime}$ East $\left(2068.5 \mathrm{~km}^{2}\right)$, which is about $25 \%$ of the total area of Western Province of Kenya. Busia District on the other hand extends from latitude $0^{\circ}$ to $0^{\circ} 45^{\prime \prime}$ North and longitude $33^{\circ} 55^{\prime}$ to $34^{\circ} 25^{\prime}$ East $\left(1262 \mathrm{~km}^{2}\right)$ with $137 \mathrm{~km}^{2}$ of its land under permanent wetland conditions.

The Simuyu drainage basin comprises of a diversity of habitats, including swampy areas, rivers, ponds, seasonally inundated grassland, bushland, and rivers. The swampy area is dominated by Cyperus papyrus, and is associated with sedges, reeds, cattails and other plant species. The floodplains and draw-downs are used for agricultural purposes.
The Simuyu Wetland extends between $33^{\circ} 23^{\prime} 30^{\prime \prime}-33^{\circ}$ $28^{\prime} 50^{\prime \prime} \mathrm{E}$ and $2^{\circ} 30^{\prime} 30^{\prime \prime}-2^{\circ} 35^{\prime} 00^{\prime \prime} \mathrm{S}$.

\section{Remote Sensing Techniques}

Satellite imagery of different dates of the three study regions were evaluated for land cover change at a temporal scale of approximately 10 year interval between 1973 and 2005. The satellite data was also used to determine areas perceived to be pollution hotspots. A Quickbird ${ }^{\circledR}$ image of March 2003 in particular was used for Nakivubo Wetland. The observation from satellite images enhanced the assessment of the impact of wetland use since 1973. After ground truth survey the land use/land cover classes established were digitized and georeferenced for geospatial analysis of the study area parameters.

\section{Participatory Research Appraisals (PRA) Methods}

The PRA methods used a variety of research tools, which included interviews, questionnaires, observations, reviewing of policy documents and previous studies on LVDB. Three types of questionnaires were used to solicit information from institutions and/or organizations such as National Environment Authority and the Lake Victoria Environment Management Program, local authorities, National Water Authorities and Lands Authorities. Indigenous knowledge in wetland use and management in the Lake Victoria Basin was sought from farmers, pastoralists, residents, brick makers, crafts makers and fishermen. 

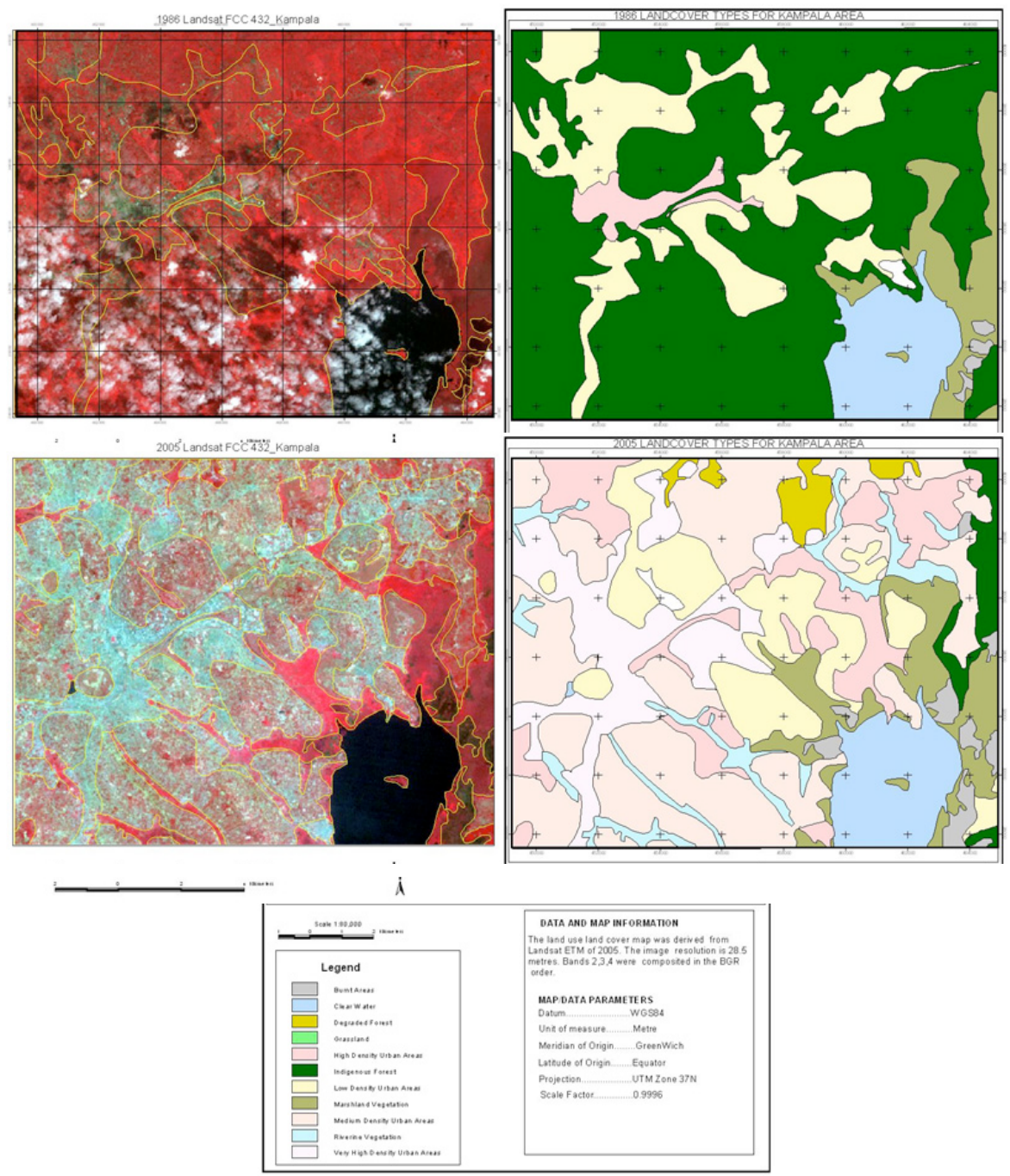

Fig. (3). Land cover changes in the Nakivubo wetland area of Kampala City as seen from Landsat images of 1986 and 2005.

\section{REVIEW OF SECONDARY DATA}

The study reviewed the progress made in crafting and implementing appropriate institutional arrangements; policy, legislations and organizational structures for addressing issues of poverty through wealth creation. Among the frameworks accessed were development plans, legislative acts and development strategy documents.

\section{Assessment of Water Quality}

The water quality in the selected sites was assessed through analysis of water and soil samples. The extent of environmental degradation from agricultural, domestic and industrial wastes and how this affects the quality of the wetland resources were examined by determining the presence of pesticides and other agricultural chemicals in water and soils from the study sites. Collection of water, effluent and soil samples from designated sites were carried out to get samples for laboratory analysis. The quality of the effluent generated by the industries within the study sites and their effects on downstream discharge was also determined. Pesticide residues in soil and water samples were determined using analytical standard methods with reference standards of selected compounds of atrazine, hexazinone, lindane and other organochlorine compounds. All other chemicals and solvents were of analytical grade.

\section{RESULTS}

The research developed and used an integrated methodology of remote sensing data on a GIS platform to analyze and present data as a basis for monitoring land cover change. Digital Landsat satellite imagery was first used to identify and map land cover features [25-28]. Document procedures used to decipher land cover patterns and the effects of anthropogenic activities using Landsat Thematic Mapper and Landsat Enhanced Thematic Mapper Plus (ETM+). The subscenes of the study area were subjected to visual interpretation and identified land cover/use changes digitized onscreen using ArcView ® software. The land cover/use was mapped based on colour hue, textural and structural values identified from the satellite imagery which were also used in delineating the land cover/use boundaries. The area under each land cover/use class was calculated and used for comparison and documentation of the temporal changes. Visual image interpretation was complemented with ground truth survey and 
Table 1. Trends in Loss of Vegetation Cover and the Built Environment in Kampala City Between 1986 and 2005

\begin{tabular}{|c|c|c|c|c|}
\hline Land Cover Type & $\begin{array}{c}\text { Year } 1986 \\
\text { km }^{2}\end{array}$ & $\begin{array}{c}\text { Year } 1995 \\
\text { km }^{2}\end{array}$ & $\begin{array}{c}\text { Year } 2001 \\
\text { km }^{2}\end{array}$ & $\begin{array}{c}\text { Year } 2005 \\
\text { km }^{2}\end{array}$ \\
\hline Burnt & 0.98 & - & - & 4.74 \\
\hline Clear & 14.99 & 14.93 & 15.03 & 14.64 \\
\hline Degraded & - & - & 0.59 & 4.75 \\
\hline Golf & - & - & - & 0.55 \\
\hline High Density Urban & 4.64 & 27.48 & 35.81 & 24.97 \\
\hline Indigenous forest & 123.154 & - & 23.87 & 5.887 \\
\hline Low Density Urban & 37.42 & 26.78 & 20.04 & 27.49 \\
\hline Marshland & - & 16.87 & 17.21 & 15.77 \\
\hline Medium Density & - & 38.6 & 53.22 & 59.7 \\
\hline Riverine & - & 6.12 & 4.47 & 10.21 \\
\hline Urban Very High Density & 0.516 & 22.04 & 24.2 & 25.725 \\
\hline Total & 181.72 & 152.84 & 194.44 & 194.432 \\
\hline
\end{tabular}

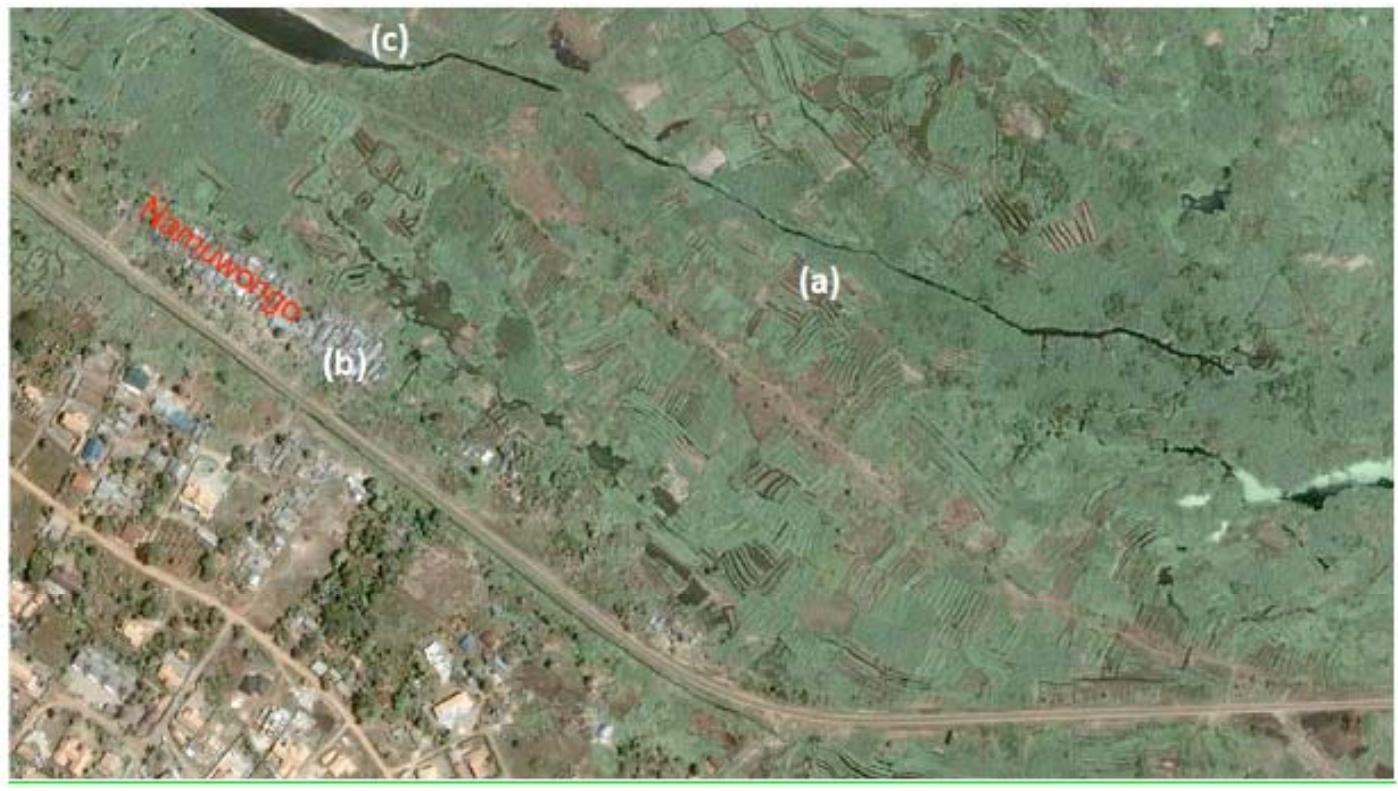

Fig. (4). QuickBird Image of Namuwongo area of Nakivubo wetland showing various land cover/use types; (a) Cultivation within the wetland; (b) Slum development at Lower Namuwongo beyond the railway line; (c) Degradation of the channel through siltation.

socio-economic data collection from the field during the field survey.

The results illustrated past and present processes impacting on the growth, development and the livelihoods of the communities in the LVDB. The following results were drawn from the interpretations of Landsat, SPOT and Quickbird satellite imagery of the three study sites.

\section{Loss of Vegetation Cover}

- The land cover characteristics of the Nakivubo watershed in Kampala interpreted from Landsat standard false colour composite (bands 432 RGB) and the classification interpretation are shown in Fig. (3) and Table 1. The data show clear evidence of environmental degradation.
- The image interpretation revealed that the indigenous forest covered a total area of $123.154 \mathrm{~km}^{2}$ in 1986. By 2005 the forest cover had reduced to a mere $5.887 \mathrm{~km}^{2}$. Another significant change is the rate of urban growth with the high and very high density settlement area growing from $0.516 \mathrm{~km}^{2}$ in 1986 to $25.725 \mathrm{~km}^{2}$ in 2005 .

The QuickBird image of $6^{\text {th }}$ March 2003 showed that there are extensive recent settlements within the Nakivubo wetlands along Namuwongo and Kitintale areas (Fig. 4). The recent settlements are distinguished by the white colour of iron sheets and are generally temporary structures. Most of these structures are normally destroyed when the National Environmental Management Authority of Uganda takes action on illegally constructed structures on wetland areas. 

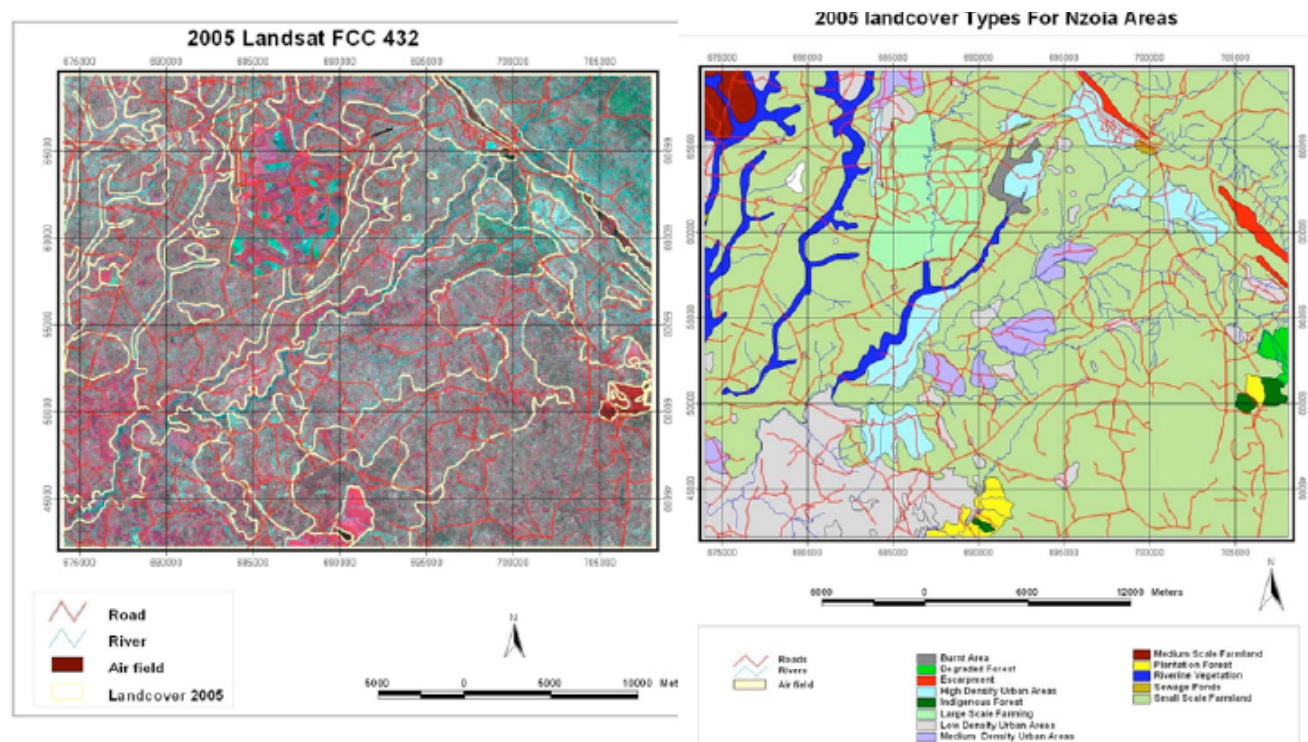

Fig. (5). Land cover/use classes interpreted from SPOT Image of 2005 for Nzoia area.

Table 2. Acreage of Land Cover/Use Classes Identified from Landsat Images of 1986, 1995, 2005 and SPOT Image of 2005 for Nzoia

\begin{tabular}{|c|c|c|c|c|}
\hline Land Cover/Use Classes & Area_1986 km² & Area_1995 km² & Area_2005 km² & Area_Spot km² \\
\hline Degraded Forest & 12.971 & 8.819 & 11.506 & 10.765 \\
\hline High Density Settlement & 5.792 & 14.225 & 13.295 & 12.372 \\
\hline Indigenous Forest & 2.589 & 2.320 & 3.274 & 3.373 \\
\hline Low Density Settlement & 24.393 & 14.934 & 7.200 & 16.232 \\
\hline Medium Density Settlement & 9.993 & 30.764 & 24.768 & 13.096 \\
\hline Medium Scale Farmland_Maize & 60.387 & 64.794 & 64.173 & 64.468 \\
\hline Mixed Farming_Medium Scale & 245.293 & 8.886 & - & - \\
\hline Plantation Forest & 1.988 & 3.300 & - & - \\
\hline Riverine Vegetation & 1.408 & 3.580 & 1.366 & 1.102 \\
\hline Sewage Ponds & 0.429 & 0.600 & 0.660 & 0.470 \\
\hline Shrubby_Grassland & 13.198 & 8.259 & - & - \\
\hline Small Scale Farming_Maize & - & 55.789 & 50.212 & 12.397 \\
\hline Small Scale_Mixed Farming & 36.292 & 263.385 & 244.036 & 261.466 \\
\hline Sugarcane Farmland_Riverine & 111.118 & 106.970 & 106.627 & 93.168 \\
\hline Sugarcane Plantation & 39.553 & 43.428 & 44.327 & 44.599 \\
\hline Sugarcane_Large Scale & - & - & 73.399 & 129.854 \\
\hline Sugarcane_Medium Scale & 84.013 & 73.137 & 189.452 & 232.072 \\
\hline Sugarcane_Medium Scale \& Veg. & - & 29.143 & - & - \\
\hline Total (medium - large scale) & 84.013 & $102.280 *$ & 262.752 & \\
\hline Sugarcane_Small Scale & 239.757 & 189.321 & 93.324 & 32.135 \\
\hline Wooded Shrubland & 44.214 & 11.730 & 5.769 & 5.817 \\
\hline TOTAL & 933.388 & 933.384 & 933.388 & 933.386 \\
\hline
\end{tabular}

The digital images of Nzoia River Drainage Basin showed the extent of degradation of both land and water resources by different economic activities. The expansion of various land use activities in different periods was interpreted from the land cover classes. The land area under me- dium scale sugarcane growing increased from $84 . \mathrm{km}^{2}$ in 1986 to $189.5 \mathrm{~km}^{2}$ in 2005 . Small scale mixed farming increased from $36.29 \mathrm{~km}^{2}$ in 1986 to $244.036 \mathrm{~km}^{2}$ in 2005 . There was a reduction in riverine vegetation from $3.6 \mathrm{~km}^{2}$ in 1995 to $1.4 \mathrm{~km}^{2}$ in 2005 (Fig. 5 and Table 2). 

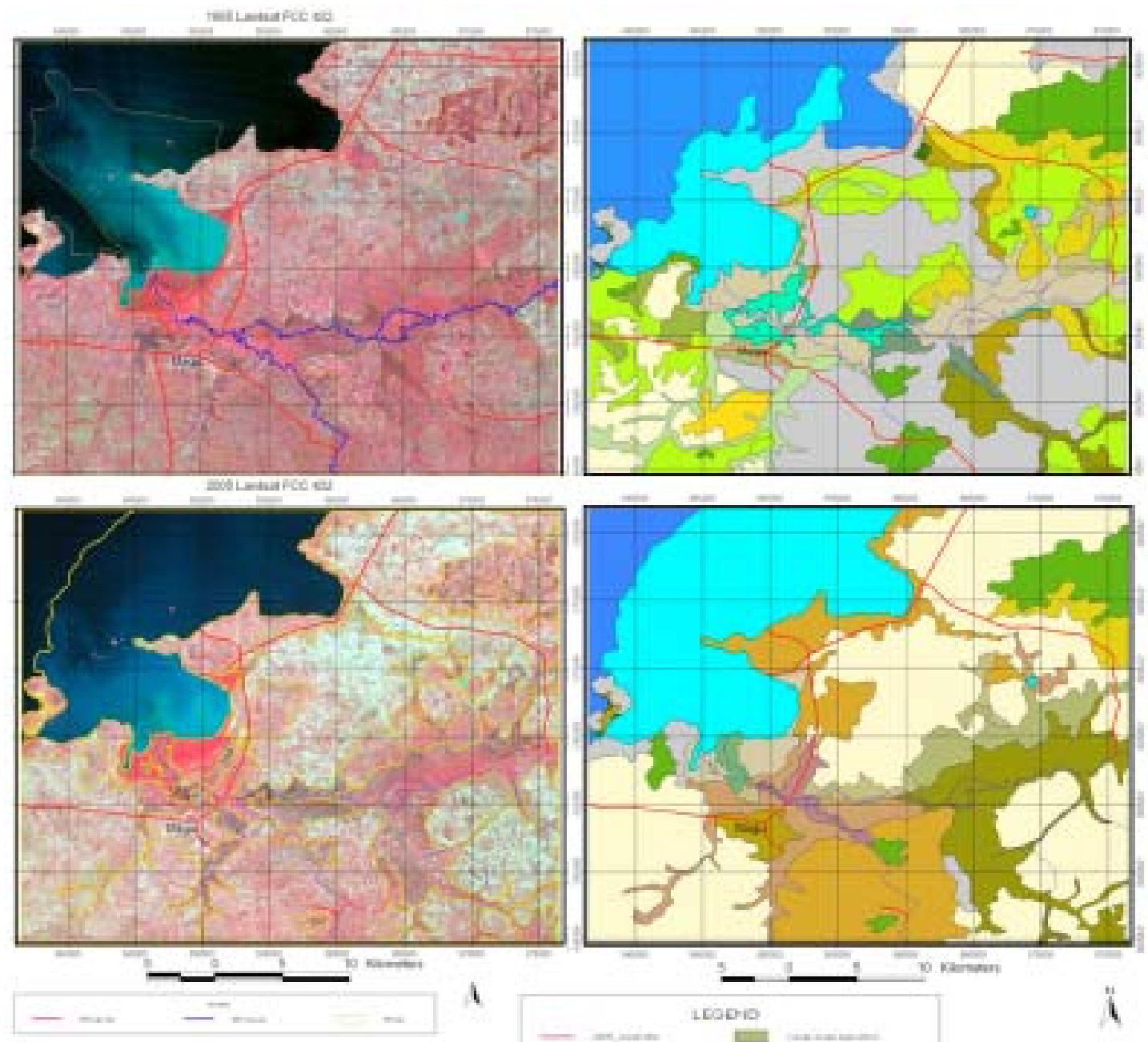

a

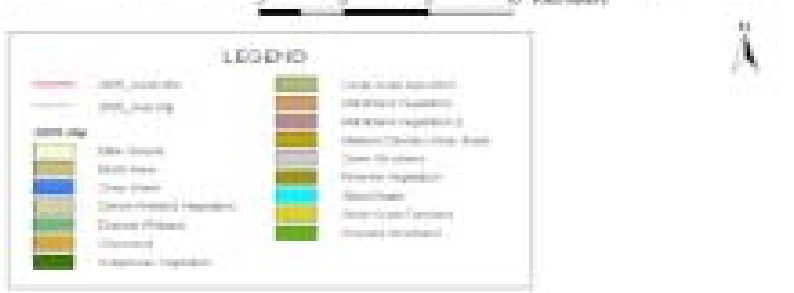

Fig. (6). Changes in land cover classes in Simiyu drainage basin at Magu from interpretation made from the 1986 and 2006 Landsat images.

Landsat satellite imagery Multispectral Scanner (MSS) Landsat $1-1 \mathrm{~m}$, Thematic Mapper (TM) Landsat $5-5 \mathrm{t}$ and Enhanced Thematic Mapper (ETM) Landsat $7-7 \mathrm{t}$ of 5 reference dates and with the following path/raw reference: p182r62_1m of 31/07/1973; p170r62_5t of 5/3/1985; p170r62_5t of 21/9/1995; p170r62_7t of 12/05/2001 and p170r60_7t of 24/06/2005 were used for land cover change analysis of the Simiyu Drainage Basin at Magu. All the images were geo-referenced and enhanced using different band combinations to facilitate interpretation. The land cover classification results from the image analysis, showed the area of land cover/use and the percentage of those areas for each of the image by dates (Fig. $\mathbf{6}$ and Table $\mathbf{3}$ ).

The broad classes of land use/cover established by interpretation included bare ground, burnt area, clear water, marshland vegetation, drained wetland, grassland, shrub land, riverine vegetation, farmland, settlements and forest. Forest cover consisted of large and dense trees with definite tree trunks. Farmland referred to cultivated areas. Riverine vegetation is vegetation along the rivers, which may be for- est or wetland grasses such as sedge grass. The settlements consisted of the built environment including urban areas and market centres.

The satellite image analysis results for the area under study showed that bare ground had increased from $160.0 \mathrm{~km}^{2}$ in 1985 to $473.5 \mathrm{~km}^{2}$ in 2005 . Drained wetland area showed that the area has reduced so much from $18 \%$ in 1985 to $0.5 \%$ in 2005. Silted water as a land cover located in Speke's Gulf had increased from $110 \mathrm{~km}^{2}$ in 1985 to $244.9 \mathrm{~km}^{2}$ in 2005 indicating an increase in silt loading on the lake waters. The marshland cover area reduced from $150.0 \mathrm{~km}^{2}$ in 1985 to $67.2 \mathrm{~km}^{2}$ in 2005 .

\section{Soil and Water Quality Data}

The soil and water quality in Nzoia River Basin was studied by analysis of industrial effluents from the Pan Paper Industry (Table 3) and soils from selected fields (Table 4).

The in-situ measurements of the physiochemical parameters (Table 3) of water indicated that dissolved phosphorous 
Table 3. In-Situ and Laboratory Measurements for Water Quality Parameters Along Nzoia River

\begin{tabular}{|c|c|c|c|c|c|c|c|c|c|}
\hline \multicolumn{2}{|c|}{ Study Site / Parameters } & \multirow{2}{*}{$\begin{array}{r}\text { Temp } \\
\left({ }^{\mathbf{0}} \mathrm{C}\right)\end{array}$} & \multirow{2}{*}{$\begin{array}{c}\mathbf{p H} \\
8.99\end{array}$} & \multirow{2}{*}{$\begin{array}{c}\begin{array}{c}\text { TDS } \\
\mathbf{m g} / \mathbf{L})\end{array} \\
167.7\end{array}$} & \multirow{2}{*}{$\begin{array}{c}\begin{array}{c}\mathbf{E C} \\
(\mathbf{m s})\end{array} \\
135\end{array}$} & \multirow{2}{*}{$\begin{array}{c}\begin{array}{c}\mathrm{DO} \\
(\mathbf{m g} / \mathbf{L})\end{array} \\
7.73\end{array}$} & \multirow{2}{*}{$\begin{array}{c}\begin{array}{c}\text { TSS } \\
(\mathbf{m g} / \mathbf{L})\end{array} \\
112\end{array}$} & \multirow{2}{*}{$\frac{\begin{array}{c}\mathrm{NO}^{3-} \\
(\mathrm{mg} / \mathrm{L})\end{array}}{10}$} & \multirow{2}{*}{$\begin{array}{c}\begin{array}{c}\mathbf{P O}^{4-} \\
(\mathrm{mg} / \mathrm{L})\end{array} \\
3\end{array}$} \\
\hline & Upstream & & & & & & & & \\
\hline \multirow[t]{2}{*}{$\begin{array}{l}\text { Pan Paper } \\
\text { Webuye }\end{array}$} & $\begin{array}{c}\text { Midstream } \\
\text { (Discharge pt) }\end{array}$ & 24.4 & 8.77 & 1179.3 & 139 & 2.05 & 540 & 2.84 & 15 \\
\hline & Downstream & 20.0 & 9.10 & 260.6 & 158 & 6.02 & 220 & 5.06 & 43 \\
\hline \multirow{3}{*}{$\begin{array}{c}\text { Nzoia } \\
\text { Sugar } \\
\text { Cooperation. }\end{array}$} & Upstream & 19.0 & 8.50 & 152.3 & 50 & 9.50 & 95 & 66.5 & 9 \\
\hline & Midstream & 19.0 & 8.95 & 153.9 & 54 & 9.35 & 120 & 114.4 & 8 \\
\hline & Downstream & 19.0 & 8.96 & 159.2 & 102 & 8.76 & 185 & 127.6 & 10 \\
\hline \multirow{3}{*}{$\begin{array}{l}\text { Mumias Sugar } \\
\text { Cooperation. }\end{array}$} & Upstream & 19.2 & 8.42 & 115.5 & 70 & 9.06 & 154 & 86.5 & 15 \\
\hline & Midstream & 20.6 & 9.12 & 115.9 & 87 & 9.50 & 141 & 120.4 & 20 \\
\hline & Downstream & 19.7 & 9.19 & 112.5 & 137. & 8.58 & 203 & 150.8 & 24 \\
\hline \multirow{3}{*}{$\begin{array}{c}\text { Lower } \\
\text { Nzoia River }\end{array}$} & Rwambwa & 20.3 & 8.35 & 114.3 & 111 & 9.76 & 125 & 55 & 12 \\
\hline & Siginga & 22.5 & 8.79 & 117.6 & 115 & 8.98 & 171 & 68 & 7 \\
\hline & Port Victoria & 23.8 & 9.08 & 115.4 & 132 & 7.50 & 214 & 48 & 5 \\
\hline $\begin{array}{l}\text { USPH } \\
\text { Stds }\end{array}$ & & 19.0 & $6.0-8.5$ & 500 & 300 & 6.0 & 50 & 45 & 0.1 \\
\hline
\end{tabular}

Table 4. Concentrations (ppb) of the Pesticide Residues in Water and Sediments Collected in November- December, 2007 from Nzoa River Basin, Kenya

\begin{tabular}{|c|c|c|c|c|c|c|c|c|c|c|c|c|}
\hline Pesticide & \multicolumn{2}{|c|}{ P1 (Water Sample) } & \multicolumn{2}{c|}{ P1 (Sediment Sample) } & \multicolumn{2}{c|}{ P2 (Water Sample) } & \multicolumn{2}{c|}{ P2 (Sediment Sample) } \\
\hline \hline Aldrin & 0.427 & \pm & 0.195 & 2.547 & \pm & 0.009 & 7.529 & \pm & 0.179 & 0.737 & \pm & 0.257 \\
\hline Dieldrin & 0.874 & \pm & 0.094 & 1.122 & \pm & 0.281 & 1.141 & \pm & 0.034 & 0.580 & \pm & 0.058 \\
\hline Endosulfan & 0.352 & \pm & 0.089 & 1.806 & \pm & 0.135 & $\mathrm{Nd}$ & & & $\mathrm{Nd}$ & \\
\hline DDT & 1.362 & \pm & 0.128 & 2.258 & \pm & 0.058 & 1.796 & \pm & 0.095 & 4.492 & \pm & 0.041 \\
\hline Permethrin & 6.253 & \pm & 0.070 & 6.049 & \pm & 0.826 & 0.902 & \pm & 0.156 & 0.582 & \pm & 0.141 \\
\hline Endrin & 0.557 & \pm & 0.303 & 1.108 & \pm & 0.747 & 0.663 & \pm & 0.180 & 0.547 & \pm & 0.100 \\
\hline Alachlor & 0.984 & \pm & 0.212 & $\mathrm{Nd}$ & & & 1.913 & \pm & 0.339 & 1.124 & \pm & 0.085 \\
\hline Diuron & 1.749 & \pm & 0.035 & 2.735 & \pm & 0.088 & 2.299 & \pm & 0.076 & $\mathrm{Nd}$ & \pm \\
\hline Atrazine & 0.142 & \pm & 0.012 & $\mathrm{Nd}$ & & & 0.037 & \pm & 0.001 & 0.218 & \pm & 0.031 \\
\hline Lindane & 0.123 & \pm & 0.003 & 0.108 & \pm & 0.002 & 0.198 & \pm & 0.007 & 0.205 & \pm & 0.014 \\
\hline Hexazinone & 0.521 & \pm & 0.126 & 0.634 & \pm & 0.021 & 1.476 & \pm & 0.012 & 3.156 & \pm & 0.215 \\
\hline
\end{tabular}

downstream were 43mg/l for (Pan Paper Co.), 10mg/l (Nzoia Sugar Co.), 24mg/l (Mumias Sugar Co.) and $5 \mathrm{mg} / \mathrm{l}$ (Lower Nzoia River, Port Victoria). The values for TSS measurements ranged between $220 \mathrm{mg} / \mathrm{l}$ to $185 \mathrm{mg} / \mathrm{l}$. The nitrate values ranged between $2.84 \mathrm{mg} / 1$ to $150.8 \mathrm{mg} / \mathrm{l}$ in various sampling points within the study site. The Electrical Conductiv- ity (EC) was highest at Pan Paper, 158ms and lowest at Nzoia Sugar Co, 102ms, (Table 3). The values shown in Table 3 from in-situ tests are an indicator of severe soil erosion resulting from land degradation. The biochemical oxygen demand indicates the levels of industrial and municipal effluents. The main sources of nitrogen and phosphorous are 
fertilizers used in the agricultural fields, livestock, urban sewage discharges and industrial effluents.

- Soils from some selected fields in Nzoia River basin showed high levels of compounds such as aldrin, dieldrin, endosulfan, DDT, endrin, alachlor (Table 4) which together are referred to as persistent organic pollutants (POPs).

\section{DISCUSSION}

\section{Nakivubo Wetland}

As revealed from the Quickbird images for Kampala, Nakivubo wetland has been subjected to a gradual process of conversion and reclamation and currently faces some of the most extreme threats and pressures. The area around Nakivubo, including the wetland itself are regarded as prime sites for urban development due to their proximity to the city centre and industrial district. The PRA results from the preliminary survey showed that Nakivubo wetland was under several anthropogenic uses. Increased agricultural development, urbanization and industrialization has increased the rate of loss of vegetation cover. Nakivubo wetland's characteristics and location means that it provides a unique and important set of services to Kampala's dwellers. It functions as a buffer through which much of the city's industrial and domestic wastewaters pass before being discharged into Lake Victoria at the Murchison Bay. Partially treated sewage from the Kampala Sewerage works is mixed with the untreated effluents already in the Nakivubo Channel before entering the wetland.

The recent rise in settlements around Nakivubo wetland is attributed to high demand for cheap accommodation by people who work as guards with the security companies located within the industrial area. A number of low income earners such as plant nursery girls and boys, workers with building companies and urban markets find cheap temporary houses built in the wetland affordable. The Banda and Kinawata settlements are predominantly of northern Uganda origin and their main business activities centre on local alcohol and the harvesting of papyrus materials from Kinawata wetland and beyond, including Luzira area.

The degraded natural and cultural characteristics of the channel reflect lack of clear authority on the channel management. Nakivubo's location makes it suitable for providing unique and important ecological services to Kampala's dwellers. The wetland functions as a buffer to the city's industrial and domestic waste water passing through to Lake Victoria at the Murchison Bay. The majority of the low-cost residential settlements in the area are excluded from the municipal sewerage system. Therefore the community discharges domestic wastes into the wetland mainly as runoff into the surface waters or through groundwater inflows from the infiltration of rainfall. On the other hand effluents from industrial wastewaters passing through Bugolobi sewage treatment works, exhibits presence of detergents, lubricants, oils, acids, xenobiotics, and organic wastes. Since the intake for Kampala's piped water works is located at the Murchison Bay near Gaba landing site which is some $4 \mathrm{~km}$ to the south west of the wetland's outflow into Murchison Bay, there is real danger for human health. Nakivubo wetland is therefore supposed to play a significant role in maintaining the quality of both the city's water supply and the open waters of the Murchison Bay part of Lake Victoria.

\section{Nzoia River Drainage Basin}

Remote sensing data for Nzoa River Drainage Basin depicted pressure on the land resources that is seen from the status of land use and land cover change. The intensification of agriculture is seen from the land being converted to medium scale and larger scale sugarcane growing from $84 \mathrm{~km}^{2}$ in 1986 through $102.28 \mathrm{~km}^{2}$ in 1995 to $262.75 \mathrm{~km}^{2}$ in 2005 most of which is in reclaimed wetland areas. Small scale mixed farming increased from $36.29 \mathrm{Km}^{2}$ in 1986 to 244.036 $\mathrm{km}^{2}$ in 2005. Trans-Nzoia Plateau occupies north of Nandi escarpment and is heavily cultivated showing a dominance of red iron-rich soils. Existing forest cover is still under threat as seen from clear cut into forest zones - one small pocket of forest remain within the image area. Forest depletion and encroachment to the Nandi Escarpment's hilly area has led to severe erosion as reflected in the high turbidity of the water and landslides often leading to loss of human lives.

The satellite images of years 1985, 1995, 2001, 2005 for Simiyu watershed indicated a progressive depletion of wetland size as seen from changes in biomass cover on the Simiyu river floodplain. The increase in size of the bare ground area is an indication of wetland degradation and a consequent replacement of wetland vegetation with bare soil that is prone to erosion. This contributes to the siltation of the lake thus increasing the lake's water turbidity because the wetland has lost its ability to filter off sediments in water entering the lake. From the satellite images, it was evident that there were levees naturally developed along the riverbank for containment of the river water. The reduction in marshland vegetation perhaps is attributed to the increased intensification of dry land rice cultivation using rain water harvesting techniques with structures known as jarubas (rectangular bounded fields, with heights from 25 to $100 \mathrm{~cm}$ ).

Analysis of the year 2005 images shows that cultivation takes places in the wetland and there is complete drainage of wetland resulting in settlement and cultivation extending to the levees and the flood plain. There was observed increase in erosion due to increased density of livestock as it was confirmed during the ground truth survey. The discharge from the river's tributaries has reduced with time probably due to grazing which leads to high evaporation.

\section{Water Quality Analysis}

The results from effluent analysis from Nzoia area clearly showed that the effluents from the industries are not adequately treated and therefore, impact negatively on the quality of the receiving waters. The quality of the water downstream points of discharge by the various industries is different from that from upstream. The degradation of Nzoia River by industrial effluents from the African paper mills was also captured in the results of analysis of the effluents from the industries. 
- Soils from some selected fields in Nzoia River basin showed high levels of compounds such as aldrin, dieldrin, endosulfan, DDT, endrin, and alachlor which together are referred to as persistent organic pollutants (POPs). The pesticides especially the organochlorines are banned in Kenya and yet were detected in the water samples showing that they are illegally applied. The pesticides are initially transported through agricultural runoffs into the water systems. The observed varying concentrations of the pesticides in the water and sediment matrices is governed by the values of partition coefficients of the pesticides between water and sediments which vary from pesticide to pesticide.

- The concentrations of the three selected herbicides in the soils depended on the frequency of application and application rate for the herbicide. Hexazinone which is the most soluble of the three compounds was found to be the highest concentration in the water samples. The detection of the pesticides in the water along the Nzoia River is due to the surface runoff from the sugarcane fields and the cultivation of rice at the Bunyala irrigation scheme. The higher concentration for the pesticides atrazine, lindane and hexazinone in sediments on the dry day could be due to reduced volume of river water leading to higher adsorption of the pesticides by sediments. The lower concentrations of lindane and atrazine in water samples collected on a dry day are due to differences in precipitation intensities prevailing. This has been documented in previous studies [29-31]. The good soils coupled with adequate moisture due to the water table in the floodplain has attracted high population density and ownership of small land units.

The environmental challenges on Nzoia River is occasioned by pollution from discharge of poorly treated effluent from sugarcane, pulping, coffee processing factories and the agricultural chemical run-offs. Effluents from the major industries in the basin but from outside the district namely paper mills, tobacco leaf factories and cotton ginnery have degraded the environment of the basin due to improper management of industrial waste. The waste is discharged into the river and the atmosphere. The pollutants have profound impacts on the fishing industry, killing fish in Nzoia River with the water unusable for any purpose for at least $20 \mathrm{~km}$ from Webuye. There have been records of death of fish at the mouth of the river. Cattle owners also find it hard to water cattle in some sections of the river.

\section{Simiyu Drainage Basin}

- The Simiyu drainage basin faces a number of threats, emanating from anthropogenic orientations. For instance, pastoralism, poses a threat to the wetland in Simuyu River Basin though it is an important aspect of livelihood support system for the rural households. Pastoralists seasonally bring their livestock from outside to graze the wetlands in the basin. This is particularly the case in times of drought, such as in 2000 , which was a particularly dry year. These wetlands are sensitive to grazing pressures and have a low carrying capacity. It was evident that the town closest to Simiyu wetland, (Mwanza) is partly serviced by a sewage system, which at present can deal with about $60 \%$ of the total effluents discharged, with the remaining percentage often finding its way into the wetland which could have serious consequences on wetland ecosystem and human health. The main effect of settlements on wetlands is reclamation (e.g. for housing, recreation areas) and eutrophication, with the latter being most pronounced in bays and near mouths of rivers and sewage outlets.

- The agricultural industries discharge organic waste, detergents, caustic soda, oils, lubricants, chlorine and dyes. Industrial effluents pose a direct threat to the wetlands because they are often discharged directly into surface waters with little or no treatment. At present, the effects are local, as industrial development is low. However, it is also highly unregulated, and as Mwanza, Musoma and Bukoba municipalities continue to grow (as is the current trend), industrial activity is likely to increase, and the amount of pollutants entering wetlands will also increase, thus affecting the water quality in the basin. The degraded natural and cultural characteristics of the three study sites reflect lack of clear authority on the management of natural resources in the Lake Victoria Basin. Similar results were obtained in a study by [32] who used three Landsat images together with socio-economic data to map the spatial dynamics of land use/cover changes to identify the urbanization process in Nairobi City. They showed a substantial decrease in forest cover and increase in the built environment between 1976 and 2000 .

\section{CONCLUSIONS}

- This study has revealed that counteractive measures against wetland degradation have been designed over the years. However, the satellite images in the period under study 1974 to 2005 based on Landsat imagery, SPOT data and Quickbird ${ }^{\circledR}$ imagery reveal that in all the three study sites the land cover has continuously reduced in size, and has been replaced by industrial, agricultural and residential activities. The implication is loss of land productivity, deteriorating ecosystem health and loss of community livelihoods. Satellite data showed a general decline in the acreage of wetlands and vegetation cover implying increased anthropogenic pressure on the wetland resources.

- The physical and chemical analysis of water quality revealed high levels of phosphates and nitrates along the agricultural zones of River Nzoia Basin. The results from effluent analysis from Nzoia area clearly showed that the effluents from the industries are not adequately treated and therefore, impact negatively on the quality of the receiving waters. 
The degradation of Nzoia River by industrial effluents from the African paper mills was also evident. The pesticides especially the organochlorines are banned in the region and yet were detected in the water samples showing that they are illegally applied. The in-situ measurements of the physiochemical parameters of water indicated that values were generally higher than the United States Public Health Standards. The higher values of Electrical Conductivity from in-situ tests are an indicator of severe soil erosion resulting from land degradation and the high values of biochemical oxygen demand indicate presence of industrial and municipal effluents. Soils from some selected fields in Nzoia River basin showed high levels of compounds such as aldrin, dieldrin, endosulfan, DDT, and endrin which are referred to as persistent organic pollutants (POPs).

\section{ACKNOWLEDGMENTS}

The authors thank Sida/SAREC for the financial support provided through the Inter-University Council for East Africa (IUCEA) under the Lake Victoria Research Initiative (VicRes). Thanks to the project participating Universities; Kyambogo University, Kenyatta University, Makerere University, Masinde Muliro University of Science and Technoloty and University of Dar es Salaam. The authors are also grateful to the Regional Centre for Mapping of Resources for Development (RCMRD) for providing the satellite images.

\section{REFERENCES}

[1] N. Chege, "Lake Victoria: A sick giant", Technical Report, World Watch Institute, 1995.

[2] S.V. Matagi, "Some issues of environmental concern in Kampala, the capital city of Uganda," Environ. Monitor. Assess., vol. 77, pp. 121-138, 2002.

[3] E.C. Odada, D.O. Olago, K. Kulindwa, M. Ntiba, and S. Wandiga, "Mitigation of environmental problems in Lake Victoria, East Africa: causal chain and policy options analysis", Ambio, vol. 33 (12), pp. 13-23, 2004

[4] R.J. Bakema, and L. Iyango, "Engaging Local Users in the Management of Wetland Resources: The Case of the National Wetlands Programme, Uganda," Working Paper No. 3. IUCN Eastern Africa Programme. Forest and Social Perspectives in Conservation, 2000.

[5] J. S. Balirwa, "Lake Victoria wetlands and the ecology of the Nile Tilapia, Oreochromis niloticus Linné, $\mathrm{PhD}$ thesis, Wagengen Agricultural University, The Netherlands, 1998.

[6] LVEMP, “About Lake Victoria” Lake Victoria Environment Management Program, Kampala, Uganda, 2004

[7] R.E. Hecky, R. Mugidde, F.W.B. Bugenyi, and X. Wang, "Phosphorus in Lake Victoria waters and sediments: sources, loadings, sinks and anthropogenic mobilization," in Proceedings of the International Conference on Lake Victoria, Jinja, Uganda, 2000.

[8] J.S. Balirwa, C.A. Chapman, C.L. Chapman, I.A. Cowx, K. Geheb, L. Kaufman, R. H. Lowe-McConnelly, O. Seehausen, J.H. Wanink, R.L. Welcomme, and F. Witte, "Biodiversity and fishery sustainability in the Lake Victoria basin: An unexpected marriage?," Bioscience, vol. 53, pp. 703-716, 2003.

[9] M.M. Kenyanya, "Observations on the limnology of Kenyan waters of Lake Victoria in relation to fisheries," in Proceedings of the International Conference on Lake Victoria, Jinja, Uganda, 2000.

[10] P.A.G.M. Scheren, H.A. Zanting, and A.M.C. Lemmens. "Estimation of water pollution sources in Lake Victoria, East Africa: Application and elaboration of the rapid assessment methodology," Environ, Manage., vol. 58, pp. 235-248, 2000.
[11] R. Mugidde, R.E. Hecky, and L. Hendzel, "Importance of planktonic N fixation in Lake Victoria", in LV2000- Conference proceedings, Jinja, Uganda, 2000.

[12] D. Kirugara, N. Nevejan, M. Masai, J. Mwamburi, and A. Othina "Identification of pollution sources in the Kenyan part of the Lake Victoria catchment area," Kenya Marine and Fisheries, Kisumu and Laboratory of General Botany and Nature Management, Free University of Brussels, Belgium, 1993.

[13] H.O. Wogenga'h, O.J. Okot, H. Keuenberger, M. Wolf, and F.W B. Bugenyi, "Pollution from point sources into the urban wetlands of Jinja Municipality, Uganda" in Proceedings of the International Conference on Lake Victoria, Jinja, Uganda, 2001.

[14] J. Ojok, "Assessment of pollution of sediments from selected Lake Victoria bays,". Msc. dissertation, Makerere University, Kampala, Uganda, 2002.

[15] A.C. Brunner, S.J. Park, G.R. Ruecker, R. Dikau, and P.L.G. Vlek, "Catenary soil development influencing erosion susceptibility along a hillslope in Uganda," Catena, vol. 58, pp. 1-2, 2004.

[16] D. Bagoora, "Assessment of runoff and soil loss on upland peasant farms in Rukiga highland eastern Kabale and the implications for environmental conservation", Ph.D. dissertation, Makerere University, Kampala, Uganda, 1997.

[17] A. Lufafa, M.M. Tenywa, M. Isabirye, M.J.G. Majaliwa, and P.L. Woomer, "Prediction of soil erosion in a Lake Victoria basin catchment using a GIS-based Universal Soil Loss model,"Agricult Sys., vol.76, pp. 883-894, 2003.

[18] J.G.M. Majaliwa, "Soil erosion from major agricultural land-uses and associated pollution loading in selected Lake Victoria microcatchments," Ph.D. dissertation, Makerere University, Kampala, 2004.

[19] R. Mulebeke, "Validation of a GIS-based USLE model in a banana-based Micro-catchment of the Lake Victoria basin," Msc. dissertation, Makerere University, Kampala, Uganda, 2004.

[20] M. Isabirye, "Land evaluation around Lake Victoria: environmental implications of land use change," Ph.D. dissertation, Katholieke Universiteit, Leuven, Belgium, 2005.

[21] J. de Vente, and J. Poesen, "Predicting soil erosion and sediment yield at the basin scale: scale issues and semi-quantitative models," Earth Sci. Revi., vol. 71, pp. 95-125, 2005.

[22] R.E. Hecky, and F.W.B. Bugenyi, "Hydrology and chemistry of the African great lakes and water-quality issues: Problems and solutions" Mitt. Int. Ver. Theor. Angew. Limnol, vol. 23, pp. 45-54, 1992.

[23] UNESCO, "Facts and figures about Lake Victoria". UNESCO water portal weekly updates No.169: Lake Victoria, December, 22 / 2006.

[24] C.K. Twesigye, S. Onywere, Z. Getenga, S. Mwakalila, and J. Nakiranda, "The Potential of Satellite Imagery and Policy Framework in Addressing Sustainable Management of Watershed Resources in the Lake Victoria Basin," Uganda Soc. J., vol. 51, pp. 74- 85, 2007.

[25] C.R. Stokes, and C.D. Clark, "Giant glacial grooves detected on Landsat ETM + Imagery," Int. J. Remote Sens., vol. 24, no. 5, pp. 905-910, March, 2003.

[26] R.K. Jaiswal, S. Mukherjee, J. Krishnamurthy, and R. Saxena "Role of Remote sensing and GIS Techniques for generation of groundwater prospect zones towards rural development - an approach," Int. J. Remote Sens., vol. 24, no. 5, pp. 993-1008, March, 2003.

[27] J.A. Griffith, S.V. Stehman, T.L. Sohl, T.R. Loveland, "Detecting trends in landscape pattern metrics over a 20 -year period using a sampling-based monitoring programme," Int. J. Remote Sens., vol. 24. 11, pp. 175-181, Jan, 2003.

[28] K.C. Seto, C.E. Woodcock, C. Song, X. Huang, J. Lu, and R. K. Kaufmann, "Monitoring land-use change in the Pearl River Delta using Landsat TM," Int. J. Remote Sens., vol. 23, no.10, pp. 19852004, May, 2002.

[29] J. Gan, R.L. Becker, W.C. Koskiren, and D.D. Buhler "Degradation of atrazine in two soils as a function of concentration," J. Environ. Qual., vol. 25, pp. 1064-1072, 1996.

[30] Z. M. Getenga, "Enhanced mineralization of Atrazine herbicide in compost-amended soil in Laboratory studies," Bul. Environ. Contam. Toxicol., vol. 71, no.5, pp. 933-941, 2003. 
[31] Z.M. Getenga, F.O. Kengara, and S.O. Wandiga, "Determination of organo-chlorine pesticide residues in soil and water from river Nyando Drainage system within Lake Victoria basin, Kenya," Bull. Environ. Contam. Toxicol.,vol. 72, pp. 335-343, 2004.
[32] C. N. Mundia and M. Aniya, "Analysis of land use/cover changes and urban expansion of Nairobi city using remote sensing and GIS," Int. J. Remote Sens., vol. 26, no. 13, pp. 2831-2849, July 2005.

Received: December 06, 2010

Revised: March 24, 2011

Accepted: March 29, 2011

(C) Twesigye et al.; Licensee Bentham Open.

This is an open access article licensed under the terms of the Creative Commons Attribution Non-Commercial License (http://creativecommons.org/licenses/by-nc/3.0/) which permits unrestricted, non-commercial use, distribution and reproduction in any medium, provided the work is properly cited. 